\title{
Asymmetric total synthesis of eicosanoid
}

\author{
Debendra K. Mohapatra* and Gorakhanath S. Yellol \\ Division of Organic Chemistry: Technology, National Chemical Laboratory \\ Pune-411008, India \\ E-mail:
}

\author{
Dedicated to Dr. A. V. Rama Rao on the occasion of his $70^{\text {th }}$ birthday \\ (received 06 Sep 04; accepted 28 Dec 04; published on the web 01 Jan 05)
}

\begin{abstract}
An asymmetric total synthesis of eicosanoid 4 starting from 2,2-dimethyl-(R)-1,3-dioxolane-4carbaldehyde is described. The key steps involved for the synthesis include modified SimmonsSmith cyclopropanation, stereoselective reduction, ring-closing metathesis (RCM) and NozakiHiyama-Kishi coupling reaction.
\end{abstract}

Keywords: Eicosanoid, lipoxygenase inhibitors, stereoselective, cyclopropanation, ring-closing metathesis

\section{Introduction}

As a part of defense mechanism, marine organisms produce a fascinating range of secondary metabolites endowed with unusual and unexpected biological profiles. The arachidonic acid pathway in marine organisms provided a number of oxylipins such as 1-3 containing the cyclopropyl-lactone groups. ${ }^{1}$ Eicosanoid 4 was isolated by the incubation of arachidonic acid with an acetone powder of the Caribbean soft coral Plexaura homomalla. ${ }^{2}$ In conjunction with other marine fatty acid metabolites (Figure 1), ${ }^{3}$ eicosanoid 4 also incorporate a cyclopropanelactone motif and lipoxygenase inhibiting activity and therefore provoked a considerable synthetic interest. $^{4 a, g}$ It is likely that the origin of eicosanoid 4 might have occurred from transformation analogous to that as constanolactones $3 .^{2}$ To expedite current pharmaceutical evaluations of this family, we describe herein an asymmetric total synthesis of eicosanoid 4. Our synthetic protocol involved modified Simmons-Smith cyclopropanation, stereoselective reduction of ketone, ring-closing metathesis (RCM) and Nozaki-Hiyama-Kishi coupling reaction (Scheme 1). 


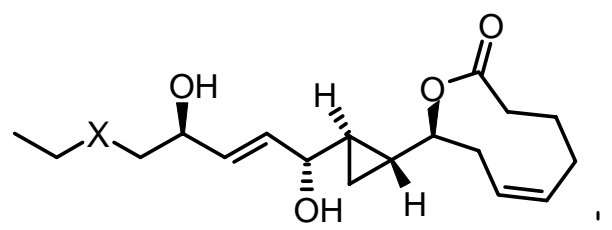

1a, $\mathrm{X}=-\mathrm{CH}_{2}-\mathrm{CH}_{2}$ - (Halicholactone)

1b, $\mathrm{X}=$ cis $-\mathrm{CH}: \mathrm{CH}$ (Neohalicholactone)

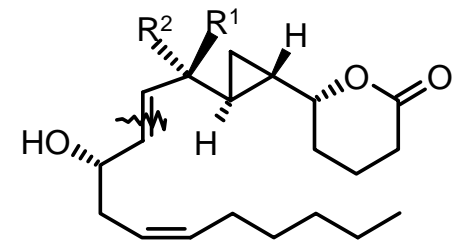

3a, $\mathrm{R}^{1}=\mathrm{H}, \mathrm{R}^{2}=\mathrm{OH}$; Constanolactone $\mathrm{A}$

3b, $\mathrm{R}^{1}=\mathrm{OH}, \mathrm{R}^{2}=\mathrm{H}$; Constanolactone $\mathrm{B}$

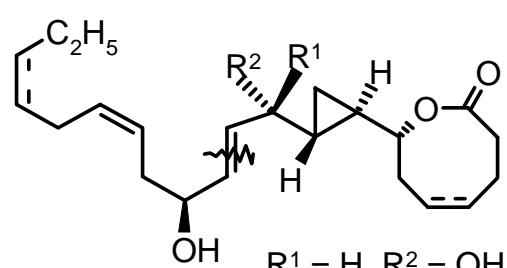

$\mathrm{R}^{1}=\mathrm{H}, \mathrm{R}^{2}=\mathrm{OH} ; \mathrm{R}^{1}=\mathrm{OH}, \mathrm{R}^{2}=\mathrm{H}$

2, Solandelactones A-H<smiles>CCCCC/C=C\CC/C=C/C(=O)[C@@H]1C[C@H]1C1CCCC(=O)O1</smiles>

Eicosanoid 4

Figure 1. Some cyclopropyl-lactone containing oxylipins.

Our interest for the synthesis of natural products in a concise manner following our general synthetic protocol, described herein is an efficient chiral pool approach taking 2,2-dimethyl- $(R)$ 1,3-dioxolane-4-carbaldehyde $\mathbf{8}$ as the starting material as depicted in the retro-synthetic analysis (Scheme 1).

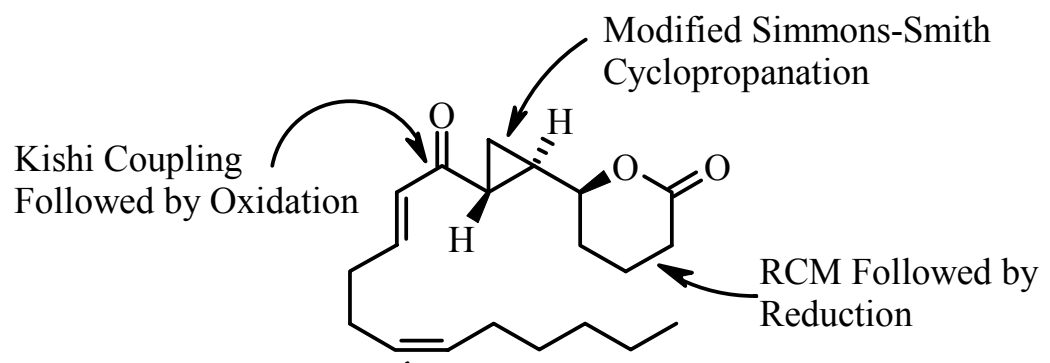

Cis-Selective

Wittig Reaction<smiles>CC1(C)OC[C@H]([C@H]2C[C@H]2[C@H]2CCCC(=O)O2)O1</smiles>

5

Eicosanoid 4

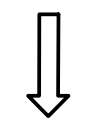

$+$

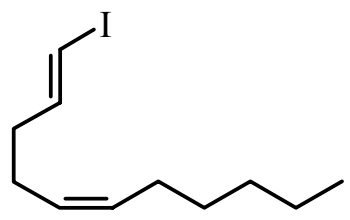

6

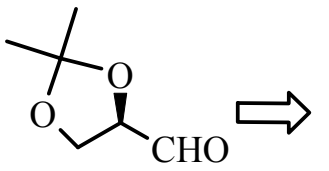

D-Mannitol

Scheme 1. Retrosynthetic analysis of Eicosanoid 4. 


\section{Results and Discussion}

Following our earlier related work, ${ }^{5 b}$ D-glyceraldehyde was converted to cyclopropyl aldehyde 13 with good overall yield. Allyl Grignard reaction on the resulting aldehyde 13 afforded compound $\mathbf{1 4}$ in a $1: 1$ diastereomeric mixture separable with difficulty by repeated column chromatography in $87 \%$ yield.
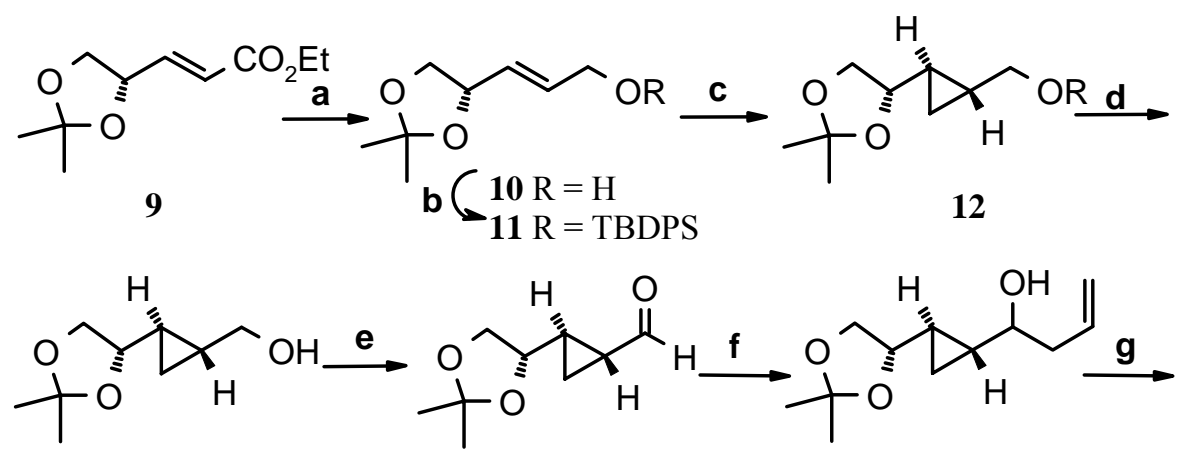

7

13

14

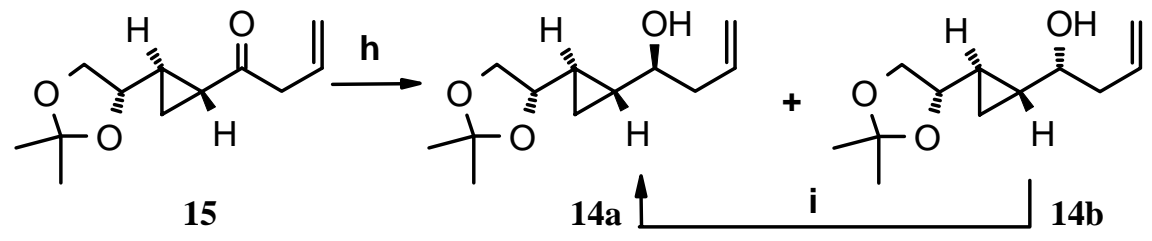

(a) DIBAL-H, $\mathrm{CH}_{2} \mathrm{Cl}_{2},-78^{\circ} \mathrm{C}$ to $0^{\circ} \mathrm{C}, 86 \%$. (b) TBDPSCl, imidazole, $\mathrm{CH}_{2} \mathrm{Cl}_{2}, 0^{\circ} \mathrm{C}$ to rt, $80 \%$. (c) $\mathrm{Et}_{2} \mathrm{Zn}, \mathrm{CH}_{2} \mathrm{I}_{2}, \mathrm{CH}_{2} \mathrm{Cl}_{2},-78^{\circ} \mathrm{C}$ to $-10^{\circ} \mathrm{C}, 95 \%$. (d) $\mathrm{Bu}_{4} \mathrm{NF}$, THF, $0^{\circ} \mathrm{C}$ to rt, $86 \%$. (e) IBX, DMSO, THF, 4h, 94\%. (f) $\mathrm{H}_{2} \mathrm{C}=\mathrm{CH}-\mathrm{CH}_{2} \mathrm{MgBr}, \mathrm{Et}_{2} \mathrm{O}$, rt, (14a/14b = 1:1), 87\%. (g) IBX, DMSO, THF, $3 \mathrm{~h}, 90 \%$. (h) K-selectride, THF, $-78^{\circ} \mathrm{C}, 4 \mathrm{~h}, 87 \%$. (i) (1) $\mathrm{EtO}_{2} \mathrm{C}-\mathrm{N}=\mathrm{N}-\mathrm{CO}_{2} \mathrm{Et}, \mathrm{PPh}_{3}$, p-nitrobenzoic acid, THF, $0^{\circ} \mathrm{C}$. (2) $\mathrm{K}_{2} \mathrm{CO}_{3}, \mathrm{MeOH}$, rt, $2 \mathrm{~h}, 76 \%$ over two steps.

Scheme 2. Reagents and conditions.

This problem was however circumvented by subjecting the homoallyl alcohol mixture to oxidation under 2-iodoxybenzoic acid (IBX) condition and selective reduction of the ketocompound with $\mathrm{K}$-selectride ${ }^{6}$ provided the diastereomers in the ratio of 9:1. The diastereomers were separated by column chromatography. The selectivity in reduction was rationalized on the basis of chelation controlled Cram's model. 

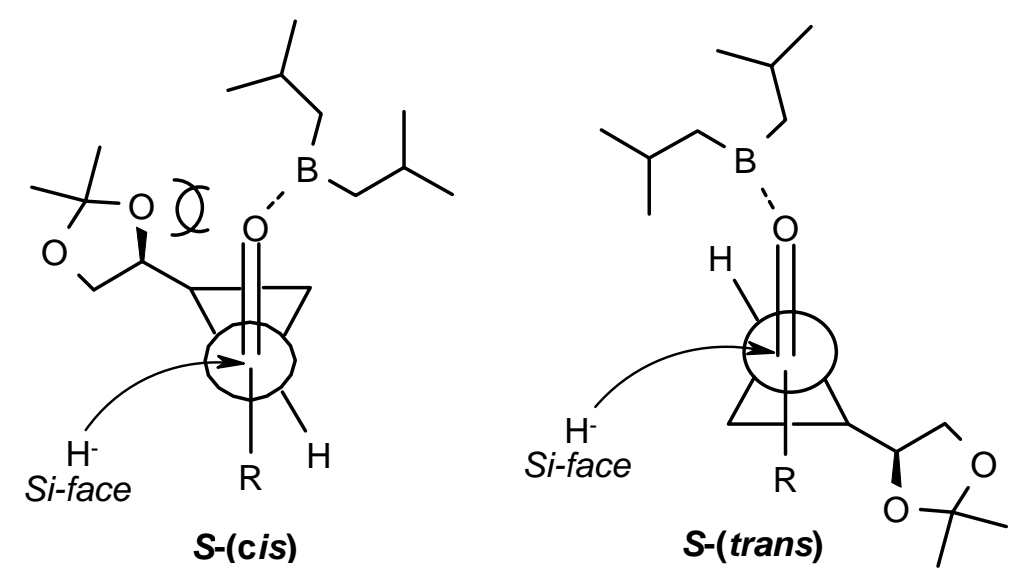

Figure 2. Conceivable transition states of the hydride reduction of cyclopropyl ketones.

Interaction between cyclopropyl $\mathrm{C}-\mathrm{C}$ bonds and carbonyl $\pi$ orbitals is maximized when the cyclopropyl and carbonyl groups are oriented orthogonally. Both the bisect (S)-(cis) and (S)(trans) conformation are able to provide maximum stabilization. Mark Lautens et al. reported that treatment of tributylsilyl cyclopropyl ketone with $\mathrm{LiBH}_{4}$ resulted in a diastereomeric mixture of 2.5:1 and explained the stereoselectivity by proposing the following (S)-(cis) model. ${ }^{7}$ But S. Shuto and co-workers reported the reverse stereoselectivity with diisobutylaluminium hydride (DIBAL-H) (Figure 2) and it was explained by (S)-(trans) model. ${ }^{6}$ When DIBAL-H is coordinated to the carbonyl group, due to steric repulsion between the two bulky isobutyl group and the substituent in the cyclopropyl group, (S)-(trans) conformation is preferred. The same argument holds true in the case of K-selectride, which demands a lot of steric repulsion due to its three sec-butyl groups. The newly created secondary hydroxyl group bearing center was assigned following modified Mosher's method. ${ }^{8}$ According to the method, the minor isomer 14b was converted to its $(R)$ - and (S)-2-methoxy-2-(trifluoromethyl)-2-phenylacetic acid (MTPA) ester with corresponding 2-methoxy-2-(trifluoromethyl)-2-phenylacetic acid which showed negative chemical shift differences $\left(\Delta \delta=\delta_{\mathrm{S}}-\delta_{\mathrm{R}}\right)$ for protons on $\mathrm{C}_{1}$ through $\mathrm{C}_{5}$ while protons on $\mathrm{C}_{7}$ through $\mathrm{C}_{9}$ showed positive differences, which is consistent with $\mathrm{C}_{6}$ bearing an $(R)$-configuration (Figure 3). The major $S$-isomer was the result of the hydride attack from the less hindered $R e$ face in the $(S)$-(trans) conformation. Although this manipulation gave the desired product 14a along with $\mathbf{1 4 b}$, the undesired intermediate was easily converted into 14a in $76 \%$ yields over two steps via standard Mitsunobu protocol. ${ }^{9}$ 


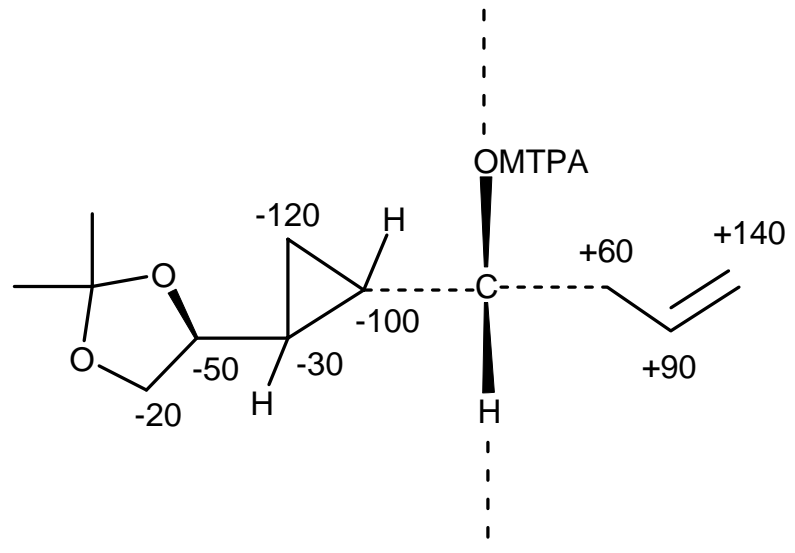

Figure 3. $\Delta \delta=\left(\delta_{\mathrm{S}}-\delta_{\mathrm{R}}\right) \times 10^{3}$ for $(R)$ - and $(S)$-MTPA esters of compound $\mathbf{1 4 \mathbf { b }}$.

The next job was to construct the six-membered lactone ring. The required isomer 14a was then treated with acryloyl chloride in $\mathrm{CH}_{2} \mathrm{Cl}_{2}$ to afford the ester 16 in $92 \%$ yield.

Ring-closing metathesis $(\mathrm{RCM})^{10}$ was then attempted on 16. So, treatment of $\mathbf{1 6}$ with Grubbs' first generation catalyst in refluxing $\mathrm{CH}_{2} \mathrm{Cl}_{2}$ provided after $36 \mathrm{~h}$ the desired sixmembered lactone 17 in 90\% yield (Scheme 3). In ${ }^{1} \mathrm{H}$ NMR of compound 17, the frequency corresponding to olefinic protons appeared at $6.72 \mathrm{ppm}$ as a multiplet and at $6.04 \mathrm{ppm}$ as a doublet and other protons at their respective regions. ${ }^{13} \mathrm{C}$ NMR was in consistent with the assigned structure and elemental analysis substantiated the proposed structure. Reduction of double bond, hydrolysis of acetonide ring followed by oxidation with $\mathrm{NaIO}_{4}$ afforded the known intermediate 20 in good overall yield. ${ }^{4 a}$
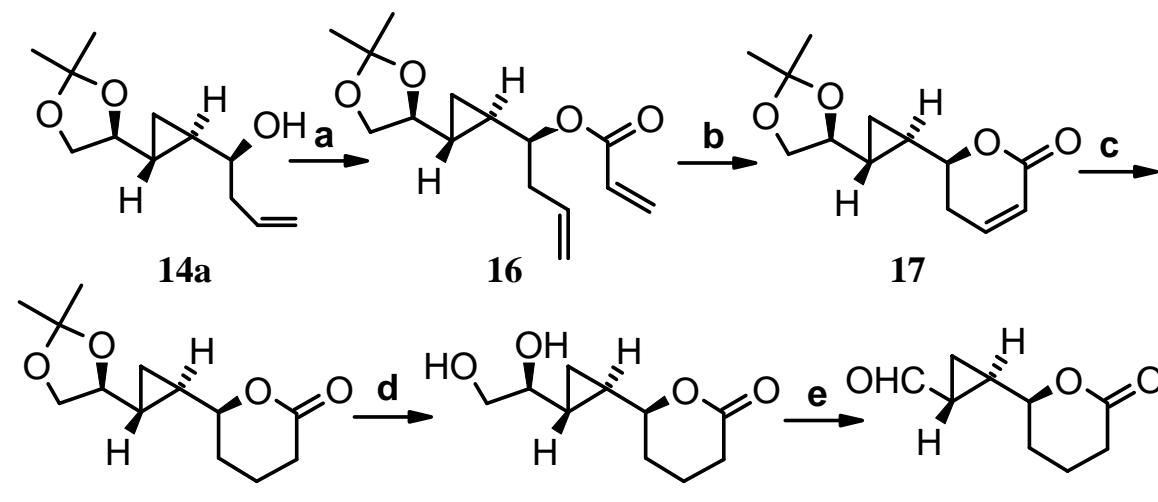

5

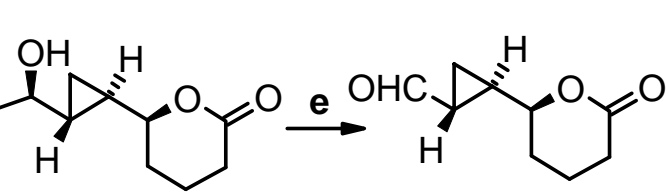

19

a) Acryloyl chloride, $\mathrm{Et}_{3} \mathrm{~N}, 0^{\circ} \mathrm{C}$ to $\mathrm{rt}, \mathrm{CH}_{2} \mathrm{Cl}_{2}, 6 \mathrm{~h}, 92 \%$. b) $\left(\mathrm{Cy}_{3} \mathrm{P}\right)_{2} \mathrm{RuCl}_{2}=\mathrm{CHPh}, \mathrm{Ti}(\mathrm{i}-\mathrm{OPr})_{4}$ (catalytic), $\mathrm{CH}_{2} \mathrm{Cl}_{2}(0.1 \mathrm{mM})$, reflux, 36h, 90\%. c) $\mathrm{Pd} / \mathrm{C}, \mathrm{H}_{2}$, Ethyl acetate, rt, 12h, 94\%. d) AcOH: $\mathrm{H}_{2} \mathrm{O}(3: 2)$, rt, 3h, 75\%. e) $\mathrm{NaIO}_{4}$ imprignated over $\mathrm{SiO}_{2}, 0^{\circ} \mathrm{C}$ to rt, $0.5 \mathrm{~h}, 94 \%$.

Scheme 3. Reagents and conditions. 
Side chain $\mathrm{C}_{10}-\mathrm{C}_{20}$ of eicosanoid 4 was prepared starting from 1,4-butanediol. Following standard reaction conditions, (1E,5Z)-1-iodo-1,5-undecadiene 6 was obtained in six steps with $42 \%$ overall yield. $^{11}$

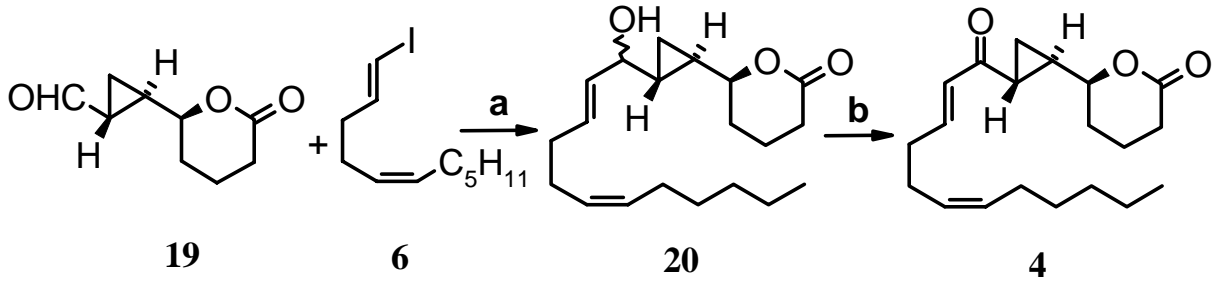

a) $\mathrm{CrCl}_{2}, \mathrm{NiCl}_{2}$ (catalytic), THF, $0^{\circ} \mathrm{C}, 24 \mathrm{~h}, 82 \%$. b) Dess-Martin periodinane, $\mathrm{CH}_{2} \mathrm{Cl}_{2}, \mathrm{rt}, 2 \mathrm{~h}$, $89 \%$.

Scheme 4. Reagents and conditions.

The final job of our endeavor was the introduction of the side chain on the cyclopropyllactone main core which was achieved smoothly by subjecting compound 6 and 19 with chromium(II) chloride and catalytic amount of nickel(II) chloride to afford the corresponding allyl alcohol 20 in a 1:1 ratio (Scheme 4). ${ }^{12}$ The total synthesis of eicosanoid 4 was completed by oxidation of the derived hydroxyl group with Dess-Martin periodinane ${ }^{13}$ in $89 \%$ yield and the obtained product was identical in all respect to the reported data of the eicosanoid $4 .^{4 \mathrm{~g}}$

\section{Conclusions}

In conclusion, we have achieved the total synthesis of eicosanoid 4 starting from 2,2-dimethyl(R)-1,3-dioxolane-4-carbaldehyde. Modified Simmons-Smith cyclopropanation, stereoselective reduction, ring-closing metathesis (RCM) and Nozaki-Hiyama-Kishi reactions have been used successfully to construct the core cyclopropyl and lactone moiety. The strategy reported herein could be applied for getting different lactone as well as side chain motifs for a diversity oriented synthesis of the above natural products for pharmacological studies and work towards this end are underway in our laboratory and will be reported in due course.

\section{Experimental Section}

General Procedures. Solvents were purified and dried by standard procedures before use. Column chromatography was carried out with silica gel (60-120 mesh). NMR spectra were recorded on Bruker AC-200 and Bruker DRX-500 machine in $\mathrm{CDCl}_{3}$ with TMS as internal standard. Mass spectra were obtained with Finningen MAT 1210 mass spectrometer. Optical rotations were measured with digital polarimeter. Elemental analysis was done on elemental analyzer model $1108 \mathrm{EA}$. All reactions were monitored on $0.25 \mathrm{~mm}$ E-Merck pre-coated silica gel (TLC) plates (60F-254) with UV or $\mathrm{I}_{2}$, anisaldehyde reagent in ethanol. Petroleum ether refers to mixture of hexanes with bp $60-80{ }^{\circ} \mathrm{C}$. 
3-[2,2-Dimethyl-(4S)-1,3-dioxolan-4-yl]-(E)-2-propen-1-ol (10). To a solution of 9 (8.0g, 40.0 $\mathrm{mmol})$ in $\mathrm{CH}_{2} \mathrm{Cl}_{2}$ was added DIBAL-H $\left(40.84 \mathrm{ml}, 1 \mathrm{M}\right.$ solution in toluene) at $-78{ }^{\circ} \mathrm{C}$. The solution was stirred for $1 \mathrm{~h}$ at same temperature and allowed to warm to $0{ }^{\circ} \mathrm{C}$ slowly. After completion of the reaction (monitored by TLC), $\mathrm{MeOH}(20 \mathrm{ml})$ was added slowly followed by the addition of cold aqueous saturated sodium potassium tartrate $(50 \mathrm{ml})$. The biphasic mixture was stirred for further $2 \mathrm{~h}$ and then partitioned. Aqueous layer was extracted with $\mathrm{CH}_{2} \mathrm{Cl}_{2}(2 \times 70$ $\mathrm{ml}$ ). Combined organic extracts were dried over $\mathrm{Na}_{2} \mathrm{SO}_{4}$ and purified by silica gel column chromatography using ethyl acetate/petroleum ether (1:4) to obtain $5.43 \mathrm{~g}(86 \%)$ of pure allyl alcohol 10 as colorless viscous liquid. $[\alpha]_{\mathrm{D}}=+32.5\left(\mathrm{c} 3.5, \mathrm{CHCl}_{3}\right) ;{ }^{1} \mathrm{H} \mathrm{NMR}(200 \mathrm{MHz}): \delta 1.35$ $(\mathrm{s}, 3 \mathrm{H}), 1.40(\mathrm{~s}, 3 \mathrm{H}), 2.80($ br s, $1 \mathrm{H}), 3.56(\mathrm{t}, J=6.2 \mathrm{~Hz}, 1 \mathrm{H}), 4.12(\mathrm{~m}, 3 \mathrm{H}), 4.52(\mathrm{~m}, 1 \mathrm{H}), 5.65$ (m, 1H), $5.88(\mathrm{~m}, 1 \mathrm{H})$; Anal. Calcd for $\mathrm{C}_{8} \mathrm{H}_{14} \mathrm{O}_{3}$ (158.20): C, 60.73; H, 8.91. Found: $\mathrm{C}, 60.24 ; \mathrm{H}$, 8.96.

(1E,4S)-tert-Butyl[3-(2,2-dimethyl-1,3-dioxolan-4-yl)-2-propenyl]oxydiphenylsilane (11). To a solution of allyl alcohol $10(5.0 \mathrm{~g}, 31.6 \mathrm{mmol})$ in $\mathrm{CH}_{2} \mathrm{Cl}_{2}(40 \mathrm{ml})$ was added imidazole $(6.45 \mathrm{~g}$, $94.9 \mathrm{mmol}$ ) at $0{ }^{\circ} \mathrm{C}$. The reaction mixture was then stirred for $15 \mathrm{~min}$ at the same temperature and tert-butyldiphenylchlorosilane (TBDPSCl) $(9.65 \mathrm{ml}, 38.0 \mathrm{mmol})$ was added. The reaction mixture was allowed to warm to room temperature and stirred overnight. After completion of the reaction (monitored by TLC), water $(20 \mathrm{ml})$ was added to it. Organic layer was separated and aqueous layer was extracted with $\mathrm{CH}_{2} \mathrm{Cl}_{2}(2 \times 50 \mathrm{ml})$. Combined organic extracts were washed successively with water and brine, dried over $\mathrm{Na}_{2} \mathrm{SO}_{4}$ and purified by silica gel column chromatography using 5\% ethyl acetate/petroleum ether to afford $10.0 \mathrm{~g}(80 \%)$ of pure silyl ether 11 as colorless liquid. $[\alpha]_{\mathrm{D}}=+22.4\left(\mathrm{c} 1.2, \mathrm{CHCl}_{3}\right) ;{ }^{1} \mathrm{H}$ NMR $(200 \mathrm{MHz}): \delta 0.98(\mathrm{~s}, 9 \mathrm{H}), 1.25(\mathrm{~s}$, $3 \mathrm{H}), 1.34(\mathrm{~s}, 3 \mathrm{H}), 3.46(\mathrm{t}, J=6.7 \mathrm{~Hz}, 1 \mathrm{H}), 3.98(\mathrm{~m}, 1 \mathrm{H}), 4.12(\mathrm{~d}, J=5.7 \mathrm{~Hz}, 2 \mathrm{H}), 4.30(\mathrm{q}, J=6.6$ $\mathrm{Hz}, 1 \mathrm{H}), 5.67(\mathrm{~m}, 2 \mathrm{H}), 7.30(\mathrm{~m}, 6 \mathrm{H}), 7.54(\mathrm{~m}, 4 \mathrm{H})$; Anal. Calcd for $\mathrm{C}_{24} \mathrm{H}_{32} \mathrm{O}_{3} \mathrm{Si}(396.61)$ : C, 72.68; H, 8.13. Found: C, 72.94; H, 8.42.

\section{(1R,2R,4S)-tert-Butyl[2-(2,2-dimethyl-1,3-dioxolan-4-yl)cyclopropyl]}

methoxydiphenylsilane (12). $\mathrm{Et}_{2} \mathrm{Zn}(142.5 \mathrm{ml}, 115.9 \mathrm{mmol}, 1 \mathrm{M}$ solution in hexane) was added dropwise to a clear solution of $\mathbf{1 1}(9.5 \mathrm{~g}, 23.2 \mathrm{mmol})$ in $\mathrm{CH}_{2} \mathrm{Cl}_{2}(200 \mathrm{ml})$ at $-78{ }^{\circ} \mathrm{C}$. After $10 \mathrm{~min}$, $\mathrm{CH}_{2} \mathrm{I}_{2}(9.3 \mathrm{ml}, 115.9 \mathrm{mmol})$ was added through syringe. The reaction mixture was stirred at the same temperature for $4 \mathrm{~h}$ and then at $-10{ }^{\circ} \mathrm{C}$ for $20 \mathrm{~h}$. The reaction mixture was poured into a saturated solution of $\mathrm{NH}_{4} \mathrm{Cl}$. Organic layer was separated and aqueous layer was extracted with $\mathrm{CH}_{2} \mathrm{Cl}_{2}(2 \times 100 \mathrm{ml})$. Combined organic extracts were washed successively with water, brine, dried over $\mathrm{Na}_{2} \mathrm{SO}_{4}$ and purified by silica gel column chromatography using ethyl acetate/petroleum ether (1:19-1:9) to give $9.34 \mathrm{~g}$ (95\%) of pure compound 12 as colorless liquid. $[\alpha]_{\mathrm{D}}=-7.7\left(\mathrm{c} 1.4, \mathrm{CHCl}_{3}\right)$, lit. $^{5}[\alpha]_{\mathrm{D}}=-7.9\left(\mathrm{c} 1.15, \mathrm{CHCl}_{3}\right) ;{ }^{1} \mathrm{H} \mathrm{NMR}(200 \mathrm{MHz}): \delta 0.54(\mathrm{~m}, 2 \mathrm{H})$, $0.72(\mathrm{~m}, 1 \mathrm{H}), 0.96(\mathrm{~m}, 1 \mathrm{H}), 1.05(\mathrm{~s}, 9 \mathrm{H}), 1.35(\mathrm{~s}, 3 \mathrm{H}), 1.40(\mathrm{~s}, 3 \mathrm{H}), 3.46(\mathrm{~m}, 2 \mathrm{H}), 3.68(\mathrm{~m}, 2 \mathrm{H})$, $4.05(\mathrm{~m}, 1 \mathrm{H}), 7.36(\mathrm{~m}, 6 \mathrm{H}), 7.64(\mathrm{~m}, 4 \mathrm{H})$; Anal. Calcd for $\mathrm{C}_{25} \mathrm{H}_{34} \mathrm{O}_{3} \mathrm{Si}$ (410.64): C, 73.12; $\mathrm{H}$, 8.34. Found: C, 72.94; $\mathrm{H}, 8.76$.

[2-(2,2-Dimethyl-(4S)-1,3-dioxolan-4-yl)-(1R,2R)-cyclopropyl]methanol (7). To a stirred solution of $12(9.0 \mathrm{~g}, 22.0 \mathrm{mmol})$ in THF $(50 \mathrm{ml})$ at $0{ }^{\circ} \mathrm{C}$, was added $\mathrm{Bu}_{4} \mathrm{NF}(32.9 \mathrm{ml}, 32.9 \mathrm{mmol}$, $1 \mathrm{M}$ solution in THF) dropwise and stirring was continued for $1 \mathrm{~h}$ at $0{ }^{\circ} \mathrm{C}$. The reaction mixture was then brought to room temperature and stirred overnight. The solvent was removed under reduced pressure and the crude product was purified by silica gel column chromatography using 
ethyl acetate/petroleum ether $(1: 4)$ to afford $3.25 \mathrm{~g}(86 \%)$ of pure compound 7 as colorless viscous liquid. $[\alpha]_{\mathrm{D}}=+16.5\left(\mathrm{c} 1.25, \mathrm{CHCl}_{3}\right) ;{ }^{1} \mathrm{H} \mathrm{NMR}(200 \mathrm{MHz}): \delta 0.63(\mathrm{~m}, 2 \mathrm{H}), 0.87(\mathrm{~m}, 1 \mathrm{H})$, $1.01(\mathrm{~m}, 1 \mathrm{H}), 1.33(\mathrm{~s}, 3 \mathrm{H}), 1.37(\mathrm{~s}, 3 \mathrm{H}), 2.68(\mathrm{br} \mathrm{s}, 1 \mathrm{H}), 3.34(\mathrm{~m}, 1 \mathrm{H}), 3.55(\mathrm{~m}, 3 \mathrm{H}), 4.05(\mathrm{~m}$, 1H); Anal. Calcd for $\mathrm{C}_{9} \mathrm{H}_{16} \mathrm{O}_{3}$ (172.23): C, 62.76; H, 9.36. Found: C, 62.84; H, 9.72.

2-[2,2-Dimethyl-(4S)-1,3-dioxolan-4-yl]-(1R,2R)-cyclopropanecarbaldehyde (13). To a stirred solution of 2-iodoxybenzoic acid (IBX) (7.81 g, $27.9 \mathrm{mmol})$ in DMSO (20 ml), was added a solution of $7(3.2 \mathrm{~g}, 18.6 \mathrm{mmol})$ in THF $(10 \mathrm{ml})$ at room temperature and stirring was continued for further $4 \mathrm{~h}$. After completion of the reaction (monitored by TLC), water $(10 \mathrm{ml})$ was added to the reaction mixture, precipitated solid was filtered off and the filtrate was diluted with water (50 $\mathrm{ml})$ and extracted with ether $(4 \times 50 \mathrm{ml})$. The combined organic layers were washed successively with aqueous $\mathrm{NaHCO}_{3}$, water, brine and dried over $\mathrm{Na}_{2} \mathrm{SO}_{4}$. The solvent was removed under reduced pressure and the crude product was purified by silica gel column chromatography using ethyl acetate/petroleum ether (1:6) to afford $2.97 \mathrm{~g}$ (94\%) of pure cyclopropyl aldehyde 13 as colorless liquid. ${ }^{1} \mathrm{H}$ NMR (200 MHz): $\delta 1.25(\mathrm{~m}, 2 \mathrm{H}), 1.35(\mathrm{~s}, 3 \mathrm{H}), 1.40(\mathrm{~s}, 3 \mathrm{H}), 1.65(\mathrm{~m}, 1 \mathrm{H})$, $1.87(\mathrm{~m}, 1 \mathrm{H}), 3.68(\mathrm{t}, J=6.2 \mathrm{~Hz}, 1 \mathrm{H}), 3.84(\mathrm{~m}, 1 \mathrm{H}), 4.10(\mathrm{~m}, 1 \mathrm{H}), 9.18(\mathrm{~d}, J=6.2 \mathrm{~Hz}, 1 \mathrm{H})$; Anal. Calcd for $\mathrm{C}_{9} \mathrm{H}_{14} \mathrm{O}_{3}$ (170.21): C, 63.50; H, 8.28. Found: C, 62.94; H, 8.36.

Grignard reaction. To an ice cooled solution of aldehyde $13(2.9 \mathrm{~g}, 17.0 \mathrm{mmol})$ in ether $(20 \mathrm{ml})$ was added dropwise to an ethereal solution of allyl magnesium bromide [prepared from allyl bromide $(2.94 \mathrm{ml}, 34.0 \mathrm{mmol})$ and $\mathrm{Mg}(1.22 \mathrm{~g}, 51.0 \mathrm{mmol})$ in ether $(50 \mathrm{ml})]$ and stirring was continued for $3 \mathrm{~h}$ at room temperature. The reaction mixture was then quenched with $5 \% \mathrm{HCl}(20$ $\mathrm{ml}$ ) and extracted with ethyl acetate $(3 \times 50 \mathrm{ml})$. The combined organic layers were washed successively with aqueous $\mathrm{NaHCO}_{3}$, water, brine and dried over $\mathrm{Na}_{2} \mathrm{SO}_{4}$. The solvent was removed under reduced pressure and the crude product was purified by silica gel column chromatography using ethyl acetate/petroleum ether (1:4) to afford $3.14 \mathrm{~g}$ (87\%) of homoallyl alcohol diastereomers 14.

1-\{2-[2,2-Dimethyl-(4S)-1,3-dioxolan-4-yl]-(1R,2R)-cyclopropyl\}-3-buten-1-one (15). To a stirred solution of 2-iodoxybenzoic acid (IBX) (4.95g, $17.7 \mathrm{mmol})$ in DMSO (30 ml), was added a solution of homoallyl alcohol $14(2.50 \mathrm{~g}, 11.8 \mathrm{mmol})$ in THF $(20 \mathrm{ml})$ at room temperature and stirring was continued for further $3 \mathrm{~h}$. After completion of the reaction (monitored by TLC), water $(10 \mathrm{ml})$ was added to the reaction mixture, precipitated solid was filtered off and the filtrate was diluted with water $(50 \mathrm{ml})$ and extracted with ether $(4 \times 50 \mathrm{ml})$. The combined organic layers were washed successively with aqueous $\mathrm{NaHCO}_{3}$, water, brine, and dried over $\mathrm{Na}_{2} \mathrm{SO}_{4}$. The solvent was removed under reduced pressure and the crude product was purified by silica gel column chromatography using ethyl acetate/petroleum ether (1:9) to afford $2.23 \mathrm{~g}(90 \%)$ of pure cyclopropyl ketone 15 as colorless liquid. $[\alpha]_{\mathrm{D}}=-59.7$ (c 1.30, $\left.\mathrm{CHCl}_{3}\right) ;{ }^{1} \mathrm{H}$ NMR $(200$ MHz): $\delta 1.08(\mathrm{~m}, 1 \mathrm{H}), 1.26(\mathrm{~m}, 1 \mathrm{H}), 1.34(\mathrm{~s}, 3 \mathrm{H}), 1.40(\mathrm{~s}, 3 \mathrm{H}), 1.63(\mathrm{~m}, 1 \mathrm{H}), 1.98(\mathrm{~m}, 1 \mathrm{H}), 3.32$ $(\mathrm{dd}, J=1.5,6.2 \mathrm{~Hz}, 2 \mathrm{H}), 3.66(\mathrm{t}, J=7.4 \mathrm{~Hz}, 1 \mathrm{H}), 3.87(\mathrm{dd}, J=6.6,8.1 \mathrm{~Hz}, 1 \mathrm{H}), 4.08(\mathrm{dd}, J=$ 6.6, 8.1 Hz, 1H), $5.19(\mathrm{~m}, 2 \mathrm{H}), 5.93(\mathrm{~m}, 1 \mathrm{H}) ;{ }^{13} \mathrm{C} \mathrm{NMR}(50 \mathrm{MHz}): \delta 14.2,24.2,25.6,26.5,26.6$, 48.5, 69.1, 76.2, 109.3, 118.9, 130.5, 206.7; Anal. Calcd for $\mathrm{C}_{12} \mathrm{H}_{18} \mathrm{O}_{3}$ (210.27): C, 68.54; $\mathrm{H}$, 8.63. Found: C, 69.22; H, 8.45.

1-\{2-[(2,2)-Dimethyl-(4S)-1,3-dioxolan-4-yl]-(1R,2R)-cyclopropyl\}-3-buten-1-ol (14a and 14b). To a stirred solution of $15(1.0 \mathrm{~g}, 4.8 \mathrm{mmol})$ in THF $(30 \mathrm{ml})$, was added K-selectride $(7.42$ 
$\mathrm{ml}, 7.4 \mathrm{mmol}, 1 \mathrm{M}$ solution in THF) at $-78{ }^{\circ} \mathrm{C}$, and stirred for $2 \mathrm{~h}$ at the same temperature. Methanol was added and the reaction mixture was brought to room temperature. After removal of the solvent at reduced pressure, the residue was treated with $2 \mathrm{M} \mathrm{NaOH}$ solution $(15 \mathrm{ml})$, extracted with ethyl acetate $(2 \times 50 \mathrm{ml})$. Combined organic layers were dried over $\mathrm{Na}_{2} \mathrm{SO}_{4}$ and concentrated to afford the crude product, which on flash chromatographic separation using ethyl acetate/petroleum ether (1:4) to afford $792 \mathrm{mg}$ of major isomer 14a and $88 \mathrm{mg}$ of minor isomer $14 b$.

1-\{2-[(2,2)-Dimethyl-(4S)-1,3-dioxolan-4-yl]-(1R,2R)-cyclopropyl\}-(1S)-3-buten-1-ol (14a). ${ }^{1} \mathrm{H}$ NMR (200 MHz): $\delta$ 0.40-0.70 (m, 2H), 0.77-1.06 (m, 2H), 1.28 (s, 3H), 1.44 (s, 3H), 2.19 (br $\mathrm{s}, 1 \mathrm{H}), 2.30(\mathrm{~m}, 2 \mathrm{H}), 3.05(\mathrm{~m}, 1 \mathrm{H}), 3.65(\mathrm{~m}, 2 \mathrm{H}), 4.06(\mathrm{~m}, 1 \mathrm{H}), 5.10(\mathrm{~m}, 2 \mathrm{H}), 5.84(\mathrm{~m}, 1 \mathrm{H}) ;{ }^{13} \mathrm{C}$ NMR (50 MHz): $\delta$ 7.9, 18.7, 21.6, 25.6, 26.7, 41.7, 69.2, 73.8, 79.1, 108.9, 118.0, 134.3; Anal. Calcd for $\mathrm{C}_{12} \mathrm{H}_{20} \mathrm{O}_{3}$ (212.29): C, 67.89; H, 9.49. Found: C, 68.24; H, 9.57.

1-\{2-[(2,2)-Dimethyl-(4S)-1,3-dioxolan-4-yl]-(1R,2R)-cyclopropyl\}-(1R)-3-buten-1-ol (14b). ${ }^{1} \mathrm{H}$ NMR (200 MHz) $\delta 0.60(\mathrm{~m}, 2 \mathrm{H}), 0.86(\mathrm{~m}, 2 \mathrm{H}), 1.28(\mathrm{~s}, 3 \mathrm{H}), 1.42(\mathrm{~s}, 3 \mathrm{H}), 1.68(\mathrm{br} \mathrm{s}, 1 \mathrm{H})$, $2.30(\mathrm{~m}, 2 \mathrm{H}), 3.07(\mathrm{~m}, 1 \mathrm{H}), 3.60(\mathrm{~m}, 2 \mathrm{H}), 4.16(\mathrm{~m}, 1 \mathrm{H}), 5.15(\mathrm{~m}, 2 \mathrm{H}), 5.84(\mathrm{~m}, 1 \mathrm{H}) ;{ }^{13} \mathrm{C} \mathrm{NMR}$ (50 MHz): $\delta$ 7.5, 18.6, 21.3, 25.6, 26.7, 41.7, 69.1, 73.5, 79.1, 108.9, 117.9, 134.4; Anal. Calcd for $\mathrm{C}_{12} \mathrm{H}_{20} \mathrm{O}_{3}$ (212.29): C, 67.89; H, 9.49. Found: C, 67.55; H, 9.26.

Mitsunobu reaction. To a solution of $14 \mathrm{~b}(1.2 \mathrm{~g}, 5.66 \mathrm{mmol})$ in $\mathrm{THF}(30 \mathrm{ml})$ was added $\mathrm{PPh}_{3}$ $(4.45 \mathrm{~g}, 17.0 \mathrm{mmol})$ and $p$-nitrobenzoic acid $(2.84 \mathrm{~g}, 17.0 \mathrm{mmol})$ and the resultant mixture was cooled to $0{ }^{\circ} \mathrm{C}$. To it, diethyl azodicarboxylate (DEAD) $(3.13 \mathrm{ml}, 19.8 \mathrm{mmol})$ diluted with THF $(5 \mathrm{ml})$ was added dropwise. The reaction mixture was then brought to room temperature and stirred overnight. After removal of the solvent, the residue was taken in $\mathrm{CH}_{2} \mathrm{Cl}_{2}$ and was washed successively with aqueous $\mathrm{NaHCO}_{3}$, water, brine, and dried over $\mathrm{Na}_{2} \mathrm{SO}_{4}$. The solvent was removed under reduced pressure and the crude product was dissolved in $\mathrm{MeOH}$ and treated with $\mathrm{K}_{2} \mathrm{CO}_{3}(0.3 \mathrm{~g})$. The solid was then filtered off, filtrate concentrated and the residue was purified by silica gel column chromatography using ethyl acetate/petroleum ether (1:5) to afford $0.91 \mathrm{~g}$ (76\% after two steps) of pure homoallyl alcohol 14a.

(S)-2-Methoxy-2-(trifluoromethyl)-2-phenylacetic acid (MTPA) ester. To a solution of 14b (20mg, $0.1 \mathrm{mmol}$ ) in $\mathrm{CH}_{2} \mathrm{Cl}_{2}(2 \mathrm{ml})$ was added (S)-2-methoxy-2-(trifluoromethyl)-2-phenylacetic acid (S-MTPA) (35mg, $0.16 \mathrm{mmol}) \mathrm{N}, \mathrm{N}$-dicyclohexyl carbodiimide (DCC) (30 mg, $0.17 \mathrm{mmol}$ ) and catalytic amount of 4-dimethylaminopyridine (DMAP). The reaction mixture was stirred overnight at room temperature. The solid was filtered off, filtrate concentrated and the residue was purified by silica gel column chromatography using ethyl acetate/petroleum ether (1:19) to afford 34mg (78\%) of pure (S)-MTPA ester. ${ }^{1} \mathrm{H}$ NMR $(200 \mathrm{MHz}): \delta 0.64(\mathrm{~m}, 1 \mathrm{H}), 0.77(\mathrm{~m}, 1 \mathrm{H})$, $0.94(\mathrm{~m}, 2 \mathrm{H}), 1.31(\mathrm{~s}, 3 \mathrm{H}), 1.39(\mathrm{~s}, 3 \mathrm{H}), 2.50(\mathrm{~m}, 2 \mathrm{H}), 3.59(\mathrm{~m}, 5 \mathrm{H}), 3.98(\mathrm{~m}, 1 \mathrm{H}), 4.67(\mathrm{~m}, 1 \mathrm{H})$, $5.15(\mathrm{~m}, 2 \mathrm{H}), 5.75(\mathrm{~m}, 1 \mathrm{H}), 7.40(\mathrm{~m}, 3 \mathrm{H}), 7.53(\mathrm{~m}, 2 \mathrm{H})$.

(R)-2-Methoxy-2-(trifluoromethyl)-2-phenylacetic acid (MTPA) ester. To a solution of 14b (20mg, $0.1 \mathrm{mmol})$ in $\mathrm{CH}_{2} \mathrm{Cl}_{2}(2 \mathrm{ml})$ was added $(R)$-2-methoxy-2-(trifluoromethyl)-2phenylacetic acid (R-MTPA) (35mg, $0.16 \mathrm{mmol}), \mathrm{DCC}(30 \mathrm{mg}, 0.17 \mathrm{mmol})$ and catalytic amount of DMAP. The reaction mixture was stirred overnight at room temperature. The solid was filtered off, filtrate concentrated and the residue was purified by silica gel column chromatography using ethyl acetate/petroleum ether $(1: 19)$ to afford $35 \mathrm{mg}(80 \%)$ of pure $(R)$ - 
MTPA ester. ${ }^{1} \mathrm{H}$ NMR (200 MHz): $\delta 0.74(\mathrm{~m}, 1 \mathrm{H}), 0.80(\mathrm{~m}, 1 \mathrm{H}), 1.06(\mathrm{~m}, 2 \mathrm{H}), 1.32(\mathrm{~s}, 3 \mathrm{H}), 1.41$ $(\mathrm{s}, 3 \mathrm{H}), 2.44(\mathrm{~m}, 2 \mathrm{H}), 3.61(\mathrm{~m}, 5 \mathrm{H}), 4.03(\mathrm{~m}, 1 \mathrm{H}), 4.60(\mathrm{~m}, 1 \mathrm{H}), 5.06(\mathrm{~m}, 2 \mathrm{H}), 5.61(\mathrm{~m}, 1 \mathrm{H})$, $7.40(\mathrm{~m}, 3 \mathrm{H}), 7.54(\mathrm{~m}, 2 \mathrm{H})$.

1[2-(2,2-Dimethyl-1,3-dioxolan-4-yl)cyclopropyl]-3-butenyl acrylate (16). Acryloyl chloride $(0.12 \mathrm{ml}, 1.4 \mathrm{mmol})$ was added dropwise to a solution of allyl alcohol 14a $(0.2 \mathrm{~g}, 0.9 \mathrm{mmol})$ and triethylamine $(0.4 \mathrm{ml}, 2.8 \mathrm{mmol})$ in $\mathrm{CH}_{2} \mathrm{Cl}_{2}(15 \mathrm{ml})$ at $0{ }^{\circ} \mathrm{C}$. After stirring for $2 \mathrm{~h}$ at $0{ }^{\circ} \mathrm{C}$, the reaction was quenched with saturated aqueous $\mathrm{NaHCO}_{3}(5 \mathrm{ml})$, poured into brine $(10 \mathrm{ml})$ and extracted with dichloromethane $(2 \times 15 \mathrm{ml})$. The combined extracts were dried over $\mathrm{Na}_{2} \mathrm{SO}_{4}$, concentrated under reduced pressure, and the residue was purified over neutral alumina using ethyl acetate/petroleum ether (1:19) to furnish ester $16(0.196 \mathrm{~g}, 92 \%)$ as a colorless oil.

* The ester was found to be unstable in $\mathrm{CDCl}_{3}$ and was used directly for the next reaction.

6-[2-(2,2-Dimethyl-1,3-dioxolan-4-yl)cyclopropyl]-5,6-dihydro-2H-pyran-2-one (17). To a stirred solution of $16(0.17 \mathrm{~g}, 0.6 \mathrm{mmol})$ in $\mathrm{CH}_{2} \mathrm{Cl}_{2}(80 \mathrm{ml})$ was added $\mathrm{Ti}(\mathrm{i}-\mathrm{OPr})_{4}(0.3 \mathrm{~mL}, 0.3$ $\mathrm{mmol}$ ) and refluxed for $1 \mathrm{~h}$. Then the temperature of the reaction mixture was brought to room temperature and a solution of bis-(tricyclohexylphosphine)[benzylidene]ruthenium(IV) dichloride (18mg, $0.06 \mathrm{mmol}$ ) in dichloromethane was added dropwise over $15 \mathrm{~min}$ at the same temperature. After refluxing for $36 \mathrm{~h}$, the solvent was removed under vacuum and the residue was purified by silica gel column chromatography using ethyl acetate/petroleum ether (1:9) to afford six-membered lactone $17(0.136 \mathrm{~g}, 90 \%)$ as a colorless liquid. $[\alpha]_{\mathrm{D}}{ }^{25}=-55.00\left(\mathrm{c} 0.95, \mathrm{CHCl}_{3}\right) ;{ }^{1} \mathrm{H}$ NMR (200 MHz): $\delta 0.62(\mathrm{~m}, 1 \mathrm{H}), 0.78(\mathrm{~m}, 1 \mathrm{H}), 1.12(\mathrm{~m}, 2 \mathrm{H}), 1.33(\mathrm{~s}, 3 \mathrm{H}), 1.41(\mathrm{~s}, 3 \mathrm{H}), 2.47$ $(\mathrm{m}, 2 \mathrm{H}), 3.68(\mathrm{~m}, 1 \mathrm{H}), 3.78(\mathrm{~m}, 2 \mathrm{H}), 4.10(\mathrm{dd}, 1 \mathrm{H}, J=5.9,8.0 \mathrm{~Hz}), 6.02(\mathrm{~d}, 1 \mathrm{H}, J=9.5 \mathrm{~Hz})$, $6.87(\mathrm{dt}, 1 \mathrm{H}, J=4.4,9.5 \mathrm{~Hz}) .{ }^{13} \mathrm{C}$ NMR $(50 \mathrm{MHz}): \delta 6.7,18.8,19.2,25.4,26.5,29.2,69.0,69.0$, 77.7, 80.6, 108.6, 121.3, 144.5, 163.5; Anal. Calcd for $\mathrm{C}_{13} \mathrm{H}_{18} \mathrm{O}_{4}$ (238.28): C, 65.53; H, 7.61. Found: C, 65.32; H, 8.07.

6-[2-(2,2-Dimethyl-1,3-dioxolan-4-yl)cyclopropyl]tetrahydro-2H-pyran-2-one (5). Palladium charcoal (20mg) was added to a stirred solution of $17(0.2 \mathrm{~g}, 0.84 \mathrm{mmol})$ in ethyl acetate $(15 \mathrm{ml})$ under hydrogen atmosphere at room temperature. After completion of the reaction (monitored by TLC), the reaction mixture was passed through a pad of silica gel and the solvent was evaporated to dryness under reduced pressure to afford the pure reduced product $5(0.19 \mathrm{~g}, 94 \%)$ as a colorless oil. $[\alpha]_{\mathrm{D}}{ }^{25}=+8.45\left(\mathrm{c} 1.15, \mathrm{CHCl}_{3}\right) ;{ }^{1} \mathrm{H} \mathrm{NMR}(500 \mathrm{MHz}): \delta 0.60(\mathrm{dt}, 1 \mathrm{H}, J=5.0,8.2$ $\mathrm{Hz}), 0.74(\mathrm{dt}, 1 \mathrm{H}, J=5.5,8.7 \mathrm{~Hz}), 0.99(\mathrm{~m}, 1 \mathrm{H}), 1.32(\mathrm{~s}, 3 \mathrm{H}), 1.08(\mathrm{~m}, 1 \mathrm{H}), 1.40(\mathrm{~s}, 3 \mathrm{H}), 1.67$ $(\mathrm{m}, 1 \mathrm{H}), 1.81(\mathrm{~m}, 1 \mathrm{H}), 1.94(\mathrm{~m}, 1 \mathrm{H}), 2.02(\mathrm{~m}, 1 \mathrm{H}), 2.44(\mathrm{ddd}, 1 \mathrm{H}, J=6.9,8.7,1.8 \mathrm{~Hz}), 2.55(\mathrm{dt}$, $1 \mathrm{H}, J=17.4,6.9 \mathrm{~Hz}), 3.66(\mathrm{~m}, 2 \mathrm{H}), 3.75(\mathrm{t}, 1 \mathrm{H}, J=7.8 \mathrm{~Hz}), 4.09(\mathrm{dd}, 1 \mathrm{H}, J=6.4,8.3 \mathrm{~Hz}) ;{ }^{13} \mathrm{C}$ NMR (125 MHz): $\delta$ 6.6, 18.2, 19.2, 19.7, 25.4, 26.5, 27.7, 29.2, 69.0, 77.8, 83.0, 108.6, 170.6; Anal. Calcd for $\mathrm{C}_{13} \mathrm{H}_{20} \mathrm{O}_{4}$ (240.30): C, 64.98; H, 8.39. Found: C, 64.63; H, 8.48.

6-[2-(1,2)-Dihydroxyethyl)cyclopropyl]tetrahydro-2H-pyran-2-one (18). A solution of 5 $(0.25 \mathrm{~g}, 1.0 \mathrm{mmol})$ in $80 \%$ aqueous $\mathrm{AcOH}: \mathrm{H}_{2} \mathrm{O}(3: 3 \mathrm{ml})$ was stirred at room temperature for $3 \mathrm{~h}$. The reaction mixture was then diluted with $\mathrm{CH}_{2} \mathrm{Cl}_{2}(20 \mathrm{ml})$ cooled to $0{ }^{\circ} \mathrm{C}$ and neutralized to $\mathrm{pH}$ 7 by adding solid $\mathrm{NaHCO}_{3}$ in small portions. The layers were then separated, aqueous layer extracted with $\mathrm{CH}_{2} \mathrm{Cl}_{2}(2 \times 15 \mathrm{ml})$ and the combined organic extracts were washed sequentially with water and brine. After drying over $\mathrm{Na}_{2} \mathrm{SO}_{4}$ and removal of solvent under reduced pressure, the residue was column chromatographied using ethyl acetate/petroleum ether (1:1) to afford the diol $18(0.16 \mathrm{~g}, 75 \%)$ as a colorless viscous liquid. 
2-(6-Oxotetrahydro-2H-pyran-2-yl)cyclopropanecarbaldehyde (19). To a vigorously stirred solution of $18(0.1 \mathrm{~g}, 0.5 \mathrm{mmol})$ in $\mathrm{CH}_{2} \mathrm{Cl}_{2}(10 \mathrm{ml})$, added in one lot suspension of $\mathrm{NaIO}_{4}$ supported on silica gel $(1.5 \mathrm{~g})$ in $\mathrm{CH}_{2} \mathrm{Cl}_{2}(10 \mathrm{ml})$ at $0{ }^{\circ} \mathrm{C}$. After stirring at the same temperature for $0.5 \mathrm{~h}$, the solid was removed by filtration, washed with $\mathrm{CH}_{2} \mathrm{Cl}_{2}(10 \mathrm{ml})$, combined filtrates were concentrated under vacuum and the residue filtered through a pad of silica gel column using ethyl acetate/petroleum ether (1:3) to afford the aldehyde $19(0.08 \mathrm{~g}, 94 \%)$ as a colorless liquid.

* This aldehyde was found to decompose on storage and was used immediately for the next reaction.

6-[2-(1-Hydroxy-2,6-dodecadienyl)cyclopropyl]tetrahydro-2H-pyran-2-one (20). To a mixture of $19(0.04 \mathrm{~g}, 0.2 \mathrm{mmol})$ and $6(0.4 \mathrm{~g}, 1.4 \mathrm{mmol})$, which had been thoroughly dried, were added degassed dimethyl formamide $(10 \mathrm{ml})$, chromium(II) chloride $(0.18 \mathrm{~g}, 1.4 \mathrm{mmol})$, and nickel(II) chloride (catalytic). The green colored solution was stirred at room temperature for $24 \mathrm{~h}$ and was poured into saturated $\mathrm{NH}_{4} \mathrm{Cl}$. Ether was then added to the resulting mixture and extracted with ether $(2 \times 20 \mathrm{ml})$, the combined organic phases were dried over $\mathrm{Na}_{2} \mathrm{SO}_{4}$ and the solvent was removed under reduced pressure.

* Compound 20 was found to be unstable at room temperature, so we proceeded for the next reaction without purification.

6-[2-(2,6-Dodecadienoyl)cyclopropyl]tetrahydro-2H-pyran-2-one (4). To a stirred solution of $20(0.09 \mathrm{~g}, 0.28 \mathrm{mmol})$ in $\mathrm{CH}_{2} \mathrm{Cl}_{2}(10 \mathrm{ml})$ was added Dess-Martin periodinane $(0.24 \mathrm{~g}, 0.56$ $\mathrm{mmol})$ at $0{ }^{\circ} \mathrm{C}$ and the suspension was stirred at room temperature for $2 \mathrm{~h}$. The reaction mixture was quenched with water and filtered through a sintered funnel. The residue was washed with $\mathrm{CH}_{2} \mathrm{Cl}_{2}(2 \times 5 \mathrm{ml})$. The organic layer was separated and aqueous layer was extracted with $\mathrm{CH}_{2} \mathrm{Cl}_{2}$ $(2 \times 5 \mathrm{ml})$. The combined extracts were dried over $\mathrm{Na}_{2} \mathrm{SO}_{4}$, and the solvent was evaporated under reduced pressure. The residue was purified by silica gel column chromatography using ethyl acetate and petroleum ether $(1: 9)$ to afford $4(0.078 \mathrm{~g}, 89 \%)$ as a colorless liquid. $[\alpha]_{\mathrm{D}}{ }^{25}=-25.76$ (c 0.60, $\left.\mathrm{CHCl}_{3}\right)$; iit. $^{4 \mathrm{~g}}[\alpha]_{\mathrm{D}}=-27.40\left(\mathrm{c} 0.46, \mathrm{CHCl}_{3}\right) ;{ }^{1} \mathrm{H} \mathrm{NMR}(500 \mathrm{MHz}): \delta 0.89(\mathrm{t}, 3 \mathrm{H}, J=6.5$ $\mathrm{Hz}), 0.97(\mathrm{~m}, 1 \mathrm{H}), 1.29(\mathrm{~m}, 7 \mathrm{H}), 1.71(\mathrm{~m}, 2 \mathrm{H}), 1.83(\mathrm{~m}, 1 \mathrm{H}), 1.95(\mathrm{~m}, 1 \mathrm{H}), 2.03(\mathrm{~m}, 3 \mathrm{H}), 2.26$ $(\mathrm{m}, 5 \mathrm{H}), 2.48(\mathrm{~m}, 1 \mathrm{H}), 2.55(\mathrm{~m}, 1 \mathrm{H}), 3.88(\mathrm{~m}, 1 \mathrm{H}), 5.33(\mathrm{~m}, 1 \mathrm{H}), 5.43(\mathrm{~m}, 1 \mathrm{H}), 6.25(\mathrm{~d}, 1 \mathrm{H}, J=$ $16.0 \mathrm{~Hz}), 6.94(\mathrm{dt}, 1 \mathrm{H}, J=15.6,6.9 \mathrm{~Hz}) ;{ }^{13} \mathrm{C} \mathrm{NMR}(125 \mathrm{MHz}): \delta 13.9,14.1,18.5,22.6,23.5$, 25.9, 27.3, 28.2 28.3, 29.5, 29.6, 31.6, 32.7, 81.5, 127.8, 130.8, 131.5, 147.5, 170.5, 197.8; MS: $\mathrm{m} / \mathrm{z}(\%)$ 351( $\left.\mathrm{M}^{+}+\mathrm{MeOH}, 90\right), 337\left(\mathrm{M}^{+}+\mathrm{H}_{2} \mathrm{O}, 100\right)$; Anal. Calcd for $\mathrm{C}_{20} \mathrm{H}_{30} \mathrm{O}_{3}$ (318.42): C, 75.43; H, 9.50. Found: C, 75.12; H, 9.83.

\section{Acknowledgements}

GSY thanks CSIR, New Delhi for award of a Research Fellowship. We are grateful to Dr. M. K Gurjar, Deputy Director \& Head, Organic Chemistry: Technology Division for his constant encouragement and support. 


\section{References}

1. (a) Gerwick, W. H. Lipids 1993, 31, 1215. (b) Gerwick, W. H. Chem. Rev. 1996, 93, 1807.

2. Baertschi, S. W.; Brash, A. R.; Harris, T. M. J. Am. Chem. Soc. 1989, 111, 5003.

3. Isolation: (a) Niwa, H.; Wakamatsu, K.; Yamada, K. Tetrahedron Lett. 1989, 30, 4543. (b) Kigoshi, H.; Niwa, H.; Yamada, K.; Stouck, T. J.; Clardy, J. Tetrahedron Lett. 1991, 2427. (c) Nagle, D. G.; Gerwick, W. H. Tetrahedron Lett. 1990, 31, 2995. (d) Nagle, D. G.; Gerwick, W. H. J. Org. Chem. 1994, 59, 7227. (e) Seo, Y.; Cho, K. W.; Rho, J. -R.; Shin, J.; Kwon, B. -M.; Bok, S. -H.; Song, J. -I. Tetrahedron 1996, 52, 10583.

4. Total synthesis of cyclopropyl-lactone containing oxylipins: (a) White, J. D.; Jensen, M. S. J. Am. Chem. Soc. 1993, 115, 2970. (b) Critcher, D. J.; Connolly, S.; Wills, M. Tetrahedron Lett. 1995, 36, 3763. (c) Critcher, D. J.; Connolly, S.; Wills, M. J. Org. Chem. 1997, 62, 6638. (d) Takemoto, Y.; Baba, Y.; Saha, G.; Naka, S.; Iwata, C.; Tanaka, T.; Ibuka, T. Tetrahedron Lett. 2000, 41, 3653. (e) Baba, Y.; Saha, G.; Naka, S.; Iwata, C.; Tanaka, T.; Ibuka, T.; Ohishi, H.; Takemoto, Y. J. Org. Chem. 2001, 66, 81. (f) Takahashi, T.; Watanabe, H.; Kitahara, T. Heterocycles 2002, 58, 99. (g) White, J. D.; Jensen, M. S. J. Am. Chem. Soc. 1995, 117, 6224. (h) Barloy-Da Silva, C.; Benkouider, A.; Pale, P. Tetrahedron Lett. 2000, 41, 3077. (i) Yu, J.; Lai, J. -Y.; Ye, J.; Balu, N.; Reddy, L. M.; Duan, W.; Fogel, E. R.; Capdevila, J. H.; Falck, J. R. Tetrahedron Lett. 2002, 43, 3939. (j) Miyaoka, H.; Shigemoto, T.; Yamada, Y. Tetrahedron Lett. 1996, 37, 7407. (k) Pietruszka, J.; Wilhelm, T. Synlett 2003, 11, 1698.

5. (a) Morikawa, T.; Sasaki, H.; Hanai, R.; Shibuya, A.; Taguchi, T. J. Org. Chem. 1994, 59, 97. (b) Vardarajan, S.; Mohapatra, D. K.; Datta, A. Tetrahedron Lett. 1998, 39, 1075.

6. Kazuta, Y.; Abe, H.; Yamamoto, T.; Matsuda, A.; Shuto, S. J. Org. Chem. 2003, 68, 3511 and references therein.

7. Lautens, M.; Delanghe, P. H. M. J. Org. Chem. 1995, 60, 2474.

8. (a) Ohtani, I.; Kusumi, J.; Kashman, Y.; Kakisawa, H. J. Am. Chem. Soc. 1991, 113, 4092. (b) Yoshida, W. Y.; Bryan, P. J.; Baker, B. J.; McClintock, J. B. J. Org. Chem. 1995, 60, 780 .

9. Mitsunobu, O. Synthesis 1981, 1.

10. For recent reviews of olefinic metathesis, see: (a) Schuster, M.; Blechert, S. Angew. Chem., Int. Ed. 1997, 36, 2037. (b) Grubbs, R. H.; Chang, S. Tetrahedron 1998, 54, 4413. (c) Armstrong, S. K. J. Chem. Soc., Perkin Trans. 1 1998, 371. (d) Schrock, R. R. Tetrahedron 1999, 55, 8141. (e) Wright, D. L. Curr. Org. Chem. 1999, 3, 211. (f) Fürstner, A. Angew. Chem., Int. Ed. 2000, 39, 3012. (g) Trnka, T. M.; Grubbs, R. H. Acc. Chem. Res. 2001, 34, 18.

11. Takai, K.; Nitta, K.; Utimoto, K. J. Am. Chem. Soc. 1986, 108, 7408.

12. Jin, H.; Uenishi, J.; Chirst, W. J.; Kishi, Y. J. Am. Chem. Soc. 1986, 108, 5644.

13. Dess, D. B.; Martin, J. C. J. Am. Chem. Soc. 1991, 113, 7277. 